
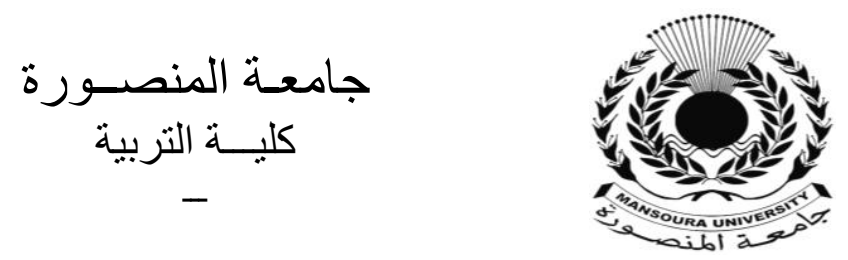

\title{
Using Edmodo Website to Improve Writing Skills of the Middle School Pupils.
}

\author{
By \\ Hadeer Eihab
}

Supereisars

Dr.Rehab Hamadtoh AbuAlghait Gohar

Prof. Dr. Aly Abdel-Samea Qoura

Journal of The Faculty of Education-Mansoura University

No. 113 - Jan . 2021 


\title{
Using Edmodo Website to Improve Writing Skills of the Middle School Pupils.
}

\section{Hadeer Eihab}

\begin{abstract}
The study aimed at investigating the impact of using Edmodo on improving writing skills of the middle school pupils. To fulfill the purpose of the study, the instrument was constructed (an EFL writing test). The instrument was administered before and after the experiment to measure the students' level. The validity and reliability of the study instrument was established before their use in the study. The quasi-experimental design had been adopted in the study. The participants of the study consisted of 28 pupils of eighth graders at Adwaa Alhedaya International Schools, in the kingdom of Saudi Arabia, where 14 pupils represented the experimental group and 14 represented the control group. Edmodo was implemented with the experimental group, whereas the control group received the regular teaching. Results of the study revealed that practicing EFL writing through Edmodo led to significant improvement in students writing skills. Therefore, it was concluded that using Edmodo as a mean of communicating and practicing the English language was highly effective in improving the participants' performance.
\end{abstract} Key words EFL writing skills, Edmodo, Egypt.

\section{Introduction}

English has been gaining importance as the most used language in the world. Continuous growth of new technologies makes English even more essential for everyone to communicate efficiently. Thus more emphasis should be given to teaching writing in English as a writing skill that may function as an important gate leading students to a successful career in this information technology driven world Warschauer(2006)

Writing is a significant skill in language production. Its significance increases when it comes to writing in English language which is extensively used for global mediation of knowledge Rahman (2002). Hyland (2003)believes that performance in language development is subject to improvement in writing skills. "Writing is the transformation of the linguistic rules of language into usage" Widdowson(2001).Thus, students should be competent and selective when they intend to produce any written discourse which demands conscious intellectual effort from learners to write coherent and meaningful paragraphs. 
Students' writing ability can be improved by fostering their interest, motivation and enjoyment for writing, through technology Graham \&Perin ( 2007). Most importantly, it is necessary that attitudes towards writing and dealing with its issues are changed. Teachers must employ strategies to elicit ideas from students to be penned down on a piece of paper to promote their verbal ability. Moreover, instant and critical feedback needs to be given on their output, so that their confidence is elevated Haide(2012).

The increase of interest in the use of computer-mediated communication (CMC)into students learning and English Language Teaching(ELT)has become a crucial part of a $21^{\text {st }}$ century education. Virtual Learning Environment as a supplementary tool for motivating and empowering independent learning and innovative teaching is practicing to deliver coursework in higher education.

Among many available technological educational tools, Edmodo has recently become very popular, it is a private micro-blogging service available at www.edmodo.com which provides a free secure learning platform. In other words, it is a social media platform often described as a facebook for education Enriquez(2014). It looks similar to facebook, but is much more private and safer for a learning environment in terms of allowing only teachers to create and manage accounts, and only their students, who receive a group code and register in the group, can access and join the group Majid(2011). Via Edmodo, teachers can send out quizzes and assignments, give feedback, receive complete assignments, assign grades, store and share content, maintain a class calendar, conduct polls and send alerts to individual students or the entire class.

By using Edmodo as the extension of the face-to-face interaction, it is expected that students can improve their English proficiency in a provided length of time, since it will increase the contact hours among students and teachers and facilitate peer feedback among students, which may create a productive learning environment for them Dewi(2014). It arises from the idea that the focus of cognitive change of an individual is created the individual mindset after the intervention of this technology tool.

The Edmodo microblogging is used as learning strategy for teaching writing. In its implementation, Edmodo is used by student to get collaborative writing activity in which students doing a writing process like planning, drafting, editing, and publishing. The utilization of Edmodo in teaching foreign language writing is focused to meet the social strategy which is very important in learning a language. 
The present study tries to assess the benefit of Edmodo which employs the principles of the theory of social constructivism. Social constructivism is a sociological theory of knowledge according to which human development is socially situated and knowledge is constructed through interaction with others Lynch(2016). The main focus of this theory is on an individual's learning that takes place because of his or her interactions in a group. An example of the constructivism theory is Edmod ;not only do the 'shape' of the software tools indicate certain things about the way online courses should work, but the activities and texts produced within the group as a whole will help shape how each person behaves within that group.

\section{Review of Literature}

\section{The writing Skill}

Researchers view writing skill differently. Leki(2004) referred to writing as a social process that requires mastering social and academic skills. Similarly, Boscolo(2006)explained the complexity of writing skill which includes cognitive, metacognitive and affective processes.

The ability to write well can have a profound impact on our lives. Writing can be an art, but it is the task of the artist to create the masterpiece. Without the competency and practice of basic writing skills, neither proficient works of written art can be fictional nor can any lives be influenced Currier(2008).

The study confirmed the importance of the writing skill to improve the students language as it evokes the ability among students to interact, create and share ideas, provide impressive and vivid words and express their thoughts smoothly. Therefore, strategies should be varied and carried out to help students express well. Keeping up with the current technological era, platforms, applying technology in the English classes has become beneficial to motivate students to participate and improve their writing skill. On behalf of that, many studies were performed to use technology to improve the writing skill.

Sandolo(2010) conducted a study to investigate how can the use of technology enhance writing in the classroom?. The study was conducted on a nine year old boy in the fourth grade at Flower Elementary. To understand how the use of technology enhances writing in the classroom, the researcher observed the boy as he goes through the writing program with the use of a word processor. The researcher observed what the boy produced without the use of the word processor and then compare to the work he produced with the use of a word processor. The results showed that doing this action 
research proved that technology enhances and motivates students to write more precise and more detailed essays.

Isa(2012) conducted a study that aimed at investigating the effect of using wikis on improving Palestinian ninth graders' English writing skills and their attitudes towards writing. The targeted skills were writing an email from notes, ordering events into a paragraph as well as writing a report from notes. To achieve this aim, the researcher employed a representative sample of 39 EFL students studying at Bureij Prep. Girls School 'A' which is run by UNRWA in the Gaza Strip. It was divided into two groups: experimental group consisted of 20 students and control one consisted of 19 students. The researcher used three tools: an observation card to explore students' performance in utilizing Wikis and practicing writing skills and activities, a questionnaire to reveal students' attitude towards using Wikis in teaching and learning writing skills and pre/ post writing test. The findings of the study revealed that there were significant differences in participants' performance before and after implementing wiki project in the favor of the post-performance. The findings also pointed toward the presence of significant differences between the attitudes of the experimental group before and after the experiment of utilizing wikis to develop their writing skills in the favor of after experiment. This was due to the wiki technology. Additionally, implementing the effect size equation, the study revealed that wiki project had a large effect size favoring the experimental group. The study recommended that teachers are asked to use the wiki technology in teaching writing skills in order to develop and improve their students' ability in writing skills

Algraini(2014) conducted a study to investigate the effect of using Padlet on enhancing female Saudi EFL learners' writing performance. The research was conducted for five weeks at the English Language Department at Al-Muzahimyah College of Education in the first semester of the academic year 2014-2015, the sample consisted of 24 students of the fifth grade. The participants were pretested to make sure that they were homogenous. Afterwards, the experimental group received an intensive training and writing classes through using padlet and the control group was instructed through the traditional lecture-discussion instruction method. At the end of the experiment, the two groups were post tested using a writing skill post-test in order to evaluate their writing skills. The findings of the study revealed that there were statistically significant differences between the means of two groups in favor of the experimental group which achieved 
better results in the post-test. Finally, the data analysis showed that Padlet was very effective in improving the participants' writing skills.

Al-Haj(2015) conducted a study aimed at examining the effectiveness of using Facebook on developing paragraph writing skills for English majors-level one at Al-Aqsa University Palestine. In order to achieve the aims of the study; the researcher adopted the quasi experimental research design. The sample of the study consisted of (30) female English majors who were purposively chosen from the Faculty of Education, AlAqsa University-Gaza. The researcher designed sessions with activities related to paragraph writing skills by using Facebook. It is worth noting that Facebook involves the following paragraph writing skills: Topic sentence, supporting sentences, concluding sentence, unity, coherence, order, completeness, grammar, punctuation and spelling) To check on the effectiveness of the target technique, the researcher constructed; pre-post paragraph writing skills test and checked on it by using a rubric. The study findings revealed that there were statistically significant differences between the scores of the paired group in the pre and post achievement test in favor of the post test. The researcher attributed these considerable results to the effectiveness of using Facebook on paragraph writing skills especially in supporting sentences, grammar, punctuation and spelling. The researcher recommended that professors at English department should adopt Facebook in teaching English in general and in teaching writing in particular.

El-Ghonaimy(2015)conducted a study to explore the effectiveness of Computer Assisted Language Learning (CALL) on the development of some English writing sub-skills (paragraph, grammar, spelling, punctuations) of ESP University students of Engineering. Participants of the study were 38 students, divided into two groups (experimental and control), with 19 each. The findings revealed that the experimental group in post-tests outperformed the control group in 3 CALL writing sub-skills (paragraph grammar and punctuation), whereas in the spelling skill, no considerable difference existed between the two groups. The study suggests that CALL English writing sub-skills could be more functional and beneficial both linguistically and socially if, as much as possible, highly-prepared computer software learning Findings of this study indicate that CALL writing subskills (paragraph, grammar, punctuation) could be more effective than the regular method for teaching English writing. Additionally, spelling skill improvement via computer teaching had the same effect on the regular one and the experimental group seemed to benefit largely from using computers in learning writing sub-skills. 
Wael(2015) investigated the effectiveness of using Edmodo as a teaching and learning virtual class to the product writing approach on enhancing Palestinian seventh graders' English writing skills and their attitudes towards writing. To achieve this aim the researcher followed the experimental approach so she chose a random sample of 50 EFL female students studying at Al-Majda Wasella prep "B" Girls school in the Directorated Education -West Gaza. The participants were divided into two equivalent groups. The findings of the study revealed that there were statistically significant difference between the main scores attained by the experimental group and that attained by the control group in the post writing test in favor of the experimental group. This means that the participants attitudes towards English writing after the implementation of the Edmodo positively changed.

Accordingly, the previous studies have proved the positive influence of modern technological strategies on improving the writing skills and students' motivation toward writing. Using padlet, wikis, facebook and Edmodo facilitate the writing process and enable students to improve their writing. Identically, Edmodo features such as searching, sharing, commenting and publishing urge students to write and provide a creative piece of writing. Edmodo is described by Trust (2012) as an interactive platform based on a social networking and mutual collaboration between teachers and students. Through Edmodo, the teachers and the students may have not only classroom activity, but also virtual learning activity. By using Edmodo, teachers can explain, deliver, and transfer the material for teaching writing.

\section{Edmodo}

Edmodo is an educational website that takes the ideas of a social network and refines them and makes it appropriate for a classroom. Edmodo is a social learning network and discussion platform where teachers and students can interact and collaborate online

Arroyo (2011) viewed Edmodo as an inspiring teaching tool for knowledge to be constructed. Edmodo is a private micro blogging service which provides a secure and free learning platform Haygood, Garner \& Johnson(2012). Sutinen (2013) showed that Edmodo might serve as a space to collaborate between students and teachers. Edmodo is a free and secure learning platform which is free of advertisements, games and other distractions used to provide a simple way for teachers to create and manage 
online classroom, and enable students to connect with teachers and other students anywhere and anytime Al-Khatiri( 2015).

Similarly, the researcher defined Edmodo as a private platform conducted by the teacher to improve the English language and the writing skill in particular. An effective platform which provides students with a lot of features to facilitate their writing process and enable them to collaborate with their peers.

Al-Kathiri(2014) conducted a research to investigate the prospects of integrating Edmodo into Saudi EFL female secondary school instruction. The research concentrates on students' perceptions and challenges regarding Edmodo use and its effect on their attitudes towards EFL learning. The 42 participants were divided into two groups. The experimental group received traditional teaching along with a six-week daily interaction via Edmodo. The control group received traditional teaching only. Findings of the posttreatment questionnaire show that students' perceptions towards Edmodo were highly positive and that although there were considerable challenges to its integration, it appeared to have excellent potential for generating more positive attitudes towards EFL learning

Wael(2015) investigated the effectiveness of using Edmodo as a teaching and learning virtual class to the product writing approach on enhancing Palestinian seventh graders' English writing skills and their attitudes towards writing. To achieve this aim the researcher followed the experimental approach so she chose a random sample of 50 EFL female students studying at Al-Majda Wasella prep "B" Girls school in the Directorated Education -West Gaza. The participants were divided into two equivalent groups. The findings of the study revealed that there were statistically significant difference between the main scores attained by the experimental group and that attained by the control group in the post writing test in favor of the experimental group. This means that the participants attitudes towards English writing after the implementation of the Edmodo positively changed.

Hastomo(2016) conducted a research to examine the effectiveness of edmodo to teach writing viewed from students' motivation This research was conducted at Senior High School in Bandar Lampung, Lampung Province. It is a quasi- experimental research.. The design of this research was a simple factorial design $2 \times 2$ with Post- Test Only Design. In the PostTest Only Design, the subject of the research was chosen to determine the Edmodo Class and Control Class. Edmodo Class was taught writing by 
using Edmodo, while the control class by using Picture Series. The population of this research was the tenth grade of Senior High School in Bandar Lampung in the academic year of 2015/ 2016.

Studies mentioned above have given momentum to Edmodo as an effective way to the teaching and learning of the EFL writing skill. Recently, Edmodo has been proved as a motivating and inspiring tool to engage students in the classroom and in English classes in particular.

\section{The pilot study}

The researcher conducted a pilot study to assess $8^{\text {th }}$ grade pupil's current level of writing skills. A selected sample was taken from Al-Raed International Schools in the kingdom of Saudi Arabia to check the pupils' writing performance. The sample included 30 female participants. The following table shows the mean score and the percentage of writing section on the writing test.

Table (1) Students' performance in the EFL writing test.

\begin{tabular}{|c|c|c|c|}
\hline Writing Skills & Mean & SD & Percentage \\
\hline Vocabulary(Word Choice) & 1.7 & .8 & $59 \%$ \\
\hline Grammar & 1.9 & .7 & $65.1 \%$ \\
\hline $\begin{array}{c}\text { Conventions(sentence } \\
\text { construction) }\end{array}$ & 1.4 & .5 & $48.4 \%$ \\
\hline Coherent writing & 1.5 & .5 & $53 \%$ \\
\hline Total & 6.7 & 1.8 & $56.4 \%$ \\
\hline
\end{tabular}

Results in table (1) indicate that pupils level in English writing in general is weak $(\mathrm{M}=6.7, \%=56.4 \& \mathrm{SD}=1.8)$ and that pupils are in need of improvement in most writing skills.

\section{Statement of the problem}

Based on the literature review, the pilot study, and the researcher experience as an English language teacher, it was apparently evident that the pupils need improvement in the writing skills. Thus, the current study investigates the effect of Edmodo Website to improve writing skills.

\section{Questions of the study}

The questions were:

1) What are the features of Edmodo website used to improve the writing skills of the eighth grade pupils of Al-Raed International school? 
2) What is the effectiveness of using Edmodo website to improve the writing skills of the eighth grade pupils of Al-Raed International school?

\section{Hypotheses}

The following hypotheses were tested:

1) There is a statistically significant difference between the mean score of the experimental and the control group on the post writing test in favor of the experimental group.

2) There is a statistically significant difference between the mean score of the experimental group pre- and post- application of the writing test in favor of the post application.

\section{Purpose}

The purpose of this study was to

1. Show how can the Edmodo be used in teaching the writing skills for the eighth grade pupils.

2. Identify the effectiveness of using Edmodo to improve writing skills of the eighth grade pupils.

\section{Definitions of Terms}

\section{Writing}

Writing is defined as an elevated work which is the product of a long process of gaining, searching, updating and sharing knowledge to create a piece of writing that reflects an advanced level of a writer. Writing is an activity that needs a process to express and impress an idea into the written form. Writing can also be viewed as a medium to share thoughts and feeling .

\section{Edmodo}

Edmodo is a virtual learning environment which provides pupils with a flexible and appropriate atmosphere to interact, share, write, express, comment and learn.

\section{Method}

\section{Participants}

The participants are two $8^{\text {th }}$ grade classes from Al-Ra'ed International School in the kingdom of Saudi Arabia. One of the classes serves as an experimental group and receives Edmodo Website activities, and the other class serves as a control group and receives the traditional teaching method. 


\section{Design}

The researcher will adopt a quasi-experimental research including two groups of the $8^{\text {th }}$ grade pupils. The following figure illustrates the experimental design of the study.

\begin{tabular}{|c|c|c|c|}
\hline \multirow{2}{*}{$\begin{array}{c}\text { Pre-writing } \\
\text { test }\end{array}$} & $\begin{array}{c}\text { Experimenta } \\
\text { 1 Group }\end{array}$ & $\begin{array}{c}\text { Using the proposed } \\
\text { Edmodo Website. }\end{array}$ & Post-writing \\
\cline { 2 - 3 } & $\begin{array}{c}\text { Control } \\
\text { Group }\end{array}$ & $\begin{array}{c}\text { Using the regular } \\
\text { teaching method. }\end{array}$ & test \\
\cline { 2 - 3 } & &
\end{tabular}

\section{Figure(1) Design of the study}

\section{Instruments}

1. A pre-post EFL writing test in addition to a rubric will be designed to measure the writing skills of the pupils.

\section{Results and Discussions}

The results of the study were statistically analyzed in terms of its hypotheses and they were discussed in the light of the theoretical background and related studies. Results of the study were reported as follows:

Table ( 2 ) Comparing the writing performance of the experimental and control groups on the post writing test

\begin{tabular}{|l|l|l|l|l|l|l|l|}
\hline \multirow{2}{*}{ Skills } & Group & $\mathbf{N}$ & $\begin{array}{l}\text { Mean } \\
\text { Rank }\end{array}$ & $\begin{array}{l}\text { Sum } \\
\text { Ranks }\end{array}$ & $\mathbf{U}$ & $\mathbf{Z}$ & Sign \\
\hline \multirow{3}{*}{ Vocabulary } & post exp & 14 & 21.50 & 301.00 & 00 & 4.591 & 0.01 \\
\cline { 2 - 9 } & post ctrl & 14 & 7.50 & 105.00 & & & \\
\hline \multirow{3}{*}{ Mechanics } & post exp & 14 & 21.29 & 298.00 & 3 & 4.459 & 0.01 \\
\cline { 2 - 9 } & post ctrl & 14 & 7.71 & 108.00 & & & \\
\hline \multirow{3}{*}{ Grammar } & post exp & 14 & 21.50 & 301.00 & 00 & 4.665 & 0.01 \\
\cline { 2 - 9 } & post ctrl & 14 & 7.50 & 105.00 & & & \\
\hline \multirow{3}{*}{ Total } & post exp & 14 & 20.79 & 291.00 & 10 & 4.196 & 0.01 \\
\cline { 2 - 9 } & post ctrl & 14 & 8.21 & 115.00 & & & \\
\cline { 2 - 9 } & post exp & 14 & 21.50 & 301.00 & 00 & 4.521 & 0.01 \\
\hline
\end{tabular}


Results in table(2) indicate that the mean score of the pupils in each writing skill in the experimental post-test was higher than that of the pupils' in the control group. Indeed, the table reports that the pupils' mean score in the overall post writing test in the experimental group was (21.50), otherwise; the pupils' mean score in the overall post writing test in the control group was (7.50). Accordingly, the above results signify the effectiveness of the proposed program on enhancing the pupils' writing skill in the experimental group.

The paired t-test results indicate that the difference between the mean score of the pupils in the post-writing test was statistically significant at the .05 level in favor of the post administration of the proposed program for the experimental group. Figure (2) shows the difference.

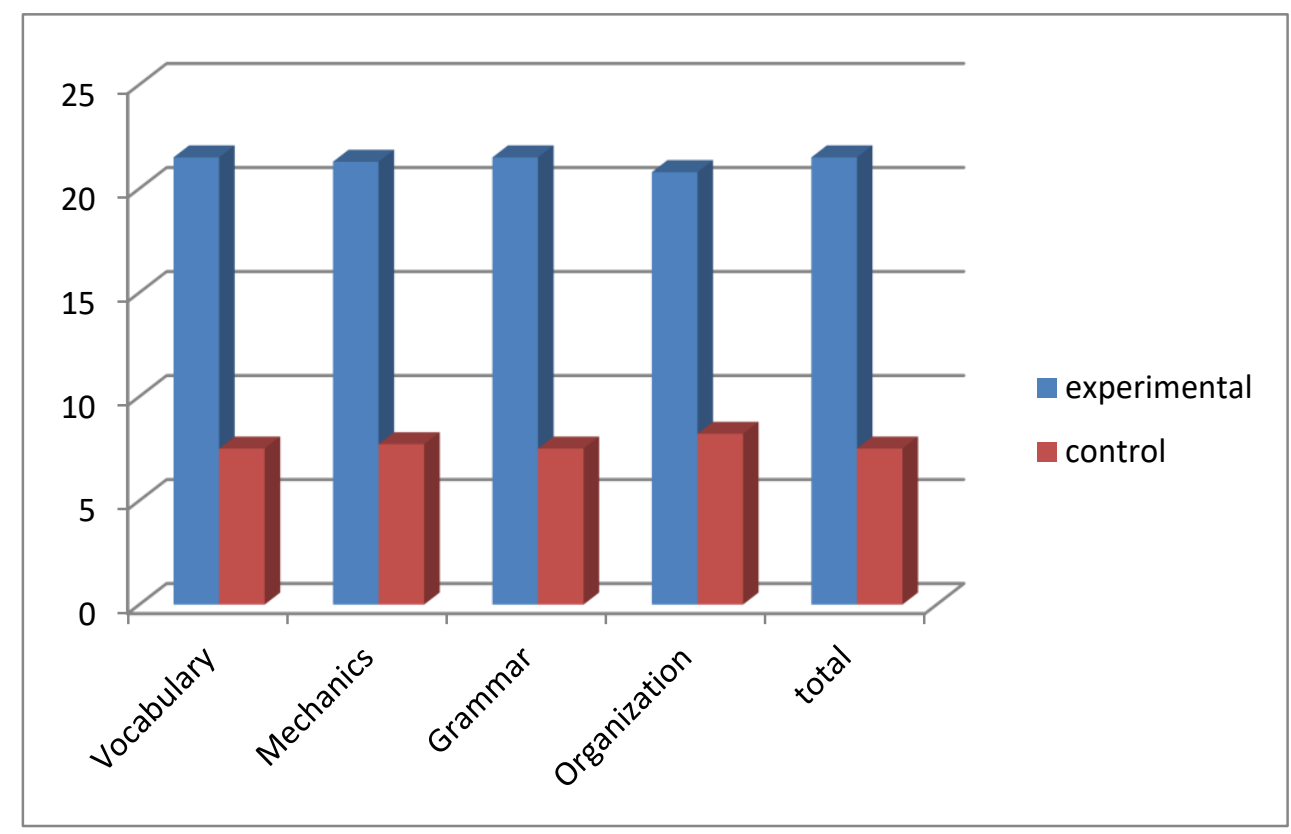

Figure (2) Mean ranks for experimental and control group in writing post test

Mean ranks for experimental and control group in writing posttest Figure (2) shows that the significant difference was in favor of the experimental group. The higher performance of the pupils in the experimental group signifies the effectiveness of the proposed program on improving the writing skills. Certainly, applying the proposed program and going through its features; contacting via Edmodo to gather information, sharing ideas and relevant essays, interacting to use expressive vocabulary words, posting the best pieces of writing, and commenting and cheering up 
all broadly contributed to the greater results of the experimental group more the traditional methods did. Besides, the proposed program made the lesson more interesting and fruitful and made the pupils more interactive, motivated and creative. On behalf of that the difference between the experimental and the control group according to them .

Table (3) Establishing the difference between the pre and post administration of the writing test on the experimental group

\begin{tabular}{|l|l|l|l|l|l|l|}
\hline Skills & \multicolumn{2}{l|l}{ Mean Rank } & \multicolumn{2}{l|}{ Sum of Ranks } & Z & Sign \\
\hline & $(-)$ & $(+)$ & $(-)$ & $(+)$ & & \\
\hline Vocabulary & 0 & 7.5 & 0 & 105 & 3.316 & 0.01 \\
\hline Mechanics & 0 & 7 & 0 & 91 & 3.247 & 0.01 \\
\hline Grammar & 0 & 7.5 & 0 & 105 & 3.440 & 0.01 \\
\hline Organization & 0 & 7.5 & 0 & 105 & 3.299 & 0.01 \\
\hline total & 0 & 7.5 & 0 & 105 & 3.304 & 0.01 \\
\hline
\end{tabular}

The above table (3) illustrates the results of the pre and post writing test which signify that the participants' mean score of each writing skill in the post test are significantly higher than the mean scores of the pre -test. Certainly, the results reflect the development in the writing skill due to the proposed program.

To sum up, The proposed Edmodo features resulted in improving writing skills. This could be attributed to encouraging students to search, share and improve creative ideas, comment on peers' pieces of writing, enrich vocabulary words and independently modify their works. This is consistent with Brozek\& Duckworth(2011) who state that through the use of the discussion board that Edmodo incorporates, students are encouraged not only to collaborate but also to participate in experiential learning as they could express themselves there, even the shyer ones, which can raise motivation. Additionally, Sanders (2012) indicates that Edmodo encourages both student engagement and responsible learning. It allows electronic collaboration through its platform where students' engagement and enjoyment in learning grows, thus making learners motivated as they engage in higher order thinking spurred by online communities. Moreover, Enriquez (2014) finds that the collaboration provided in Edmodo enabled students to improve their work.

The results prove that there is an obvious improvement in the writing skills of the experimental group students, as compared to their performance 
before conducting the experimental treatment. According to this, the hypotheses of the study were proved and accepted

\section{Conclusion}

All in all, the results and the previous studies show the influential Edmodo in the learning environment especially the writing skill. Edmodo has sufficiently turned the monotonous writing class into a lively writing environment run by active and creative pupils.

\section{Recommendations}

In the light of the achieved results, the researcher recommends that schools should take into their accounts the technological revolution and how to implement it effectively in the school. Schools should provide a helpful technical environment with all the resources which qualify both the teacher and the students to go through an effective learning process. Similarly, parents should be aware of all the facilities to help their kids. Identically, it is a sharing task between the school board and the parents at home.

1. Teachers should abandon the traditional methods of the monotonous classical class seeking modern methods for a modern English class.

2. Teachers should update their knowledge technically by joining IT courses to be able to handle any challenges while using the program.

3. Teachers should enrich their knowledge academically and search to supply videos, links, images, and all new age requirements to cope with the students' advanced needs.

4. The school should activate the program to include all the subjects along with the students' portfolios, report cards, notifications, certificates of appreciation.... etc, to enable the students to easily and constantly log in and interact.

\section{References}

Algraini, F. N. A. (2014). The effect of using padlet on enhancing EFL writing performance. Al-Imam Muhammad Ibn Saud Islamic University.

Candrasari, M. (2015). The Use of Edmodo Website to Improve Students Writing Skill (Classroom Action Research of the tenth grade students of SMKN 1 Wonosegoro in academic 2015/2016) (Doctoral dissertation, IAIN Salatiga).

Fauzi, A. (2017). The effect of Edmodo on students' writing skill in recount text. International Journal of Pedagogy and Teacher Education, 1(2), 73-79. 
Graham, S., \& Perin, D. (2007). Writing next-effective strategies to improve writing of adolescents in middle and high schools.

Hastomo, T. (2016). The effectiveness of Edmodo to teach writing viewed from students' motivation. In International Conference on Teacher Training and Education. Sebelas Maret University.

Hidi, S., \& Boscolo, P. (2006). Motivation and writing. Handbook of writing research, 144(157), 304-310.

Hosseini, M., Taghizadeh, M. E., Abedin, M. J. Z., \& Naseri, E. (2013). In the importance of EFL learners' writing skill: Is there any relation between writing skill and content score of English essay test. International Letters of Social and Humanistic Sciences, 6(1), 112.

Hyland, F. (2003). Focusing on form: Student engagement with teacher feedback. System, 31(2), 217-230.

Sandolo, L. (2010). How can the use of Technology enhance writing in the classroom?.

Silva, T., \& Leki, I. (2004). Family matters: The influence of applied linguistics and composition studies on second language writing studies-Past, present, and future. The Modern Language Journal, 88(1), 1-13.

Ware, P. D., \& Warschauer, M. (2006). Electronic feedback and second language writing. Feedback in second language writing: Contexts and issues, 105-122. 